\title{
EFEKTIFITAS PENGGUNAAN SMART BOX EDUCATION DALAM PEMBERIAN PENYULUHAN KESEHATAN PADA PASIEN GANGGUAN PERSYARAFAN DI POLI SYARAF
}

\author{
Agus Khoirul Anam \\ Jurusan Keperawatan, Poltekkes Kemenkes Malang \\ *Email:aguskhoirulanam@gmail.com
}

\begin{abstract}
Abstrak
Penyuluhan kesehatan merupakan cara yang digunakan untuk menyampaikan informasi kesehatan. Penyuluhan dapat dilakukan langsung melalui metode tatap muka atau dengan menggunakan media massa sebagai sarana dalam penyampaian informasi. Untuk itu, perlu dilakukan promosi kesehatan melalui PKRS yang bisa memberikan penjelasan kepada masyarakat mengenai pentingnya kesehatan. Poli syaraf RSUD Ngudi Waluyo Wlingi merupakan salah satu pelayanan poliklinik yang mempunyai kunjungan terbanyak yaitu 800 kunjungan per bulan, pada bulan November 2017 sekitar 20-50 pengunjung Poli Syaraf tidak memanfaatkan waktu luangnya untuk membaca leaflet promosi kesehatan, keengganan membaca leaflet dan jumlah perawat di poli hanya 1 sehingga tidak sempat untuk memberikan penyuluhan kesehatan. Tujuan penelitian ini mengidentifikasi efektifitas penggunaan smart box education dalam pemberian penyuluhan kesehatan pada keluarga pasien gangguan persyarafan di poli syaraf RSUD Ngudi Waluyo Wlingi. Desain Quasi-Experimental Pretest-Posttest dengan sampel penelitian sebanyak 25 orang. Pengambilan sampel dilakukan dengan cara simple random sampling. Kelompok perlakuan diberikan tindakan menggunakan Smart Box education. Variabel yang diukur adalah efektifitas penggunaan smart box education dalam pemberian penyuluhan kesehatan kelompok perlakuan dan kelompok kontrol. Hasil penelitian menyatakan bahwa ada pengaruh penggunaan smart box education dalam pemberian penyuluhan kesehatan dilakukan uji Wilcoxon dengan tingkat kemaknaan $\mathrm{p} 0,002(\mathrm{p} \leq 0,05)$. Saran dalam penelitian ini bahwa smart box education dapat digunakan sebagai sarana peningkatan layanan penyuluhan kesehatan di poli Syaraf.
\end{abstract}

Kata kunci : Penyuluhan kesehatan, Smart Box Education, Leaflet

\begin{abstract}
Effectiveness Of The Use Of Smart Box Education In Giving Health Education In Patients Of Nervous Disorders In Neurological Clinic: Health education is a method used to convey health information. Counseling can be done directly through the face-to-face method or by using mass media as a means of delivering information. It is necessary to promote health through PKRS that can provide an explanation to the public about the importance of health. The neural poly Ngudi Waluyo Wlingi Regional Hospital is one of the polyclinic services that has the most visits, 800 visits per month in November 2017 around 20-50 visitors to Poly Nerve did not use their free time to read health promotion leaflets and also the reluctance to read leaflets. The purpose of this study was to identify the effectiveness of using smart box education in providing health education to the families of patients at the nerve clinic of Ngudi Waluyo Wlingi Regional Hospital. This study uses a Quasi-Experimental Pretest-Posttest design with a sample of 25 people. Sampling was conducted by simple random sampling. For the treatment group, actions were given using Smart Box education. The measured variable is the effectiveness of using smart box education in the provision of health education in the treatment group and the control group. The results of the study stated that there was an influence of the use of smart box education in the provision of health education Wilcoxon test with a significance level of p 0.002 ( $p(0.05)$. Suggestions in this study that smart box education can be used as a means of improving services health education at Poly Nerve.
\end{abstract}

Keywords: Health education, Smart Box Education, Leaflets 


\section{Pendahuluan}

Kesadaran masyarakat akan masalah kesehatan masih sangat rendah. Baik kesehatan diri sendiri, keluarga, maupun kesehatan lingkungan. Untuk itu, perlu dilakukan promosi kesehatan yang bisa memberikan penjelasan kepada masyarakat mengenai pentingnya kesehatan (Haryani, 2016). Penyuluhan kesehatan merupakan cara yang digunakan untuk menyampaikan informasi kesehatan. Penyuluhan dapat dilakukan langsung melalui metode tatap muka atau dengan menggunakan media massa sebagai sarana dalam penyampaian informasi. Pada kenyataannya belum diketahui cara mana yang paling efektif dalam penyuluhan kesehatan untuk perawatan hipertensi usia dewasa ( Setiawan, 2017). Poli syaraf RSUD Ngudi Waluyo Wlingi merupakan salah satu pelayanan poliklinik yang mempunyai kunjungan terbanyak yaitu 800 kunjungan per bulan. Studi pendahuluan pada bulan November 2017 sekitar 20-50 pengunjung Poli Syaraf tidak memanfaatkan waktu luangnya untuk membaca leaflet promosi kesehatan, dan juga keengganan membaca leaflet. Disamping itu disebabkan jumlah perawat di poli hanya 1 dan administrasi 1 sehingga tidak sempat untuk memberikan penyuluhan kesehatan.
Smart box education adalah perangkat alat modern yang bersifat elektronik karya inovatif peneliti yang dipergunakan untuk mempermudahkan seseorang dalam mendapatkan penyuluhan kesehatan, di mana dasarnya banyak pengunjung yang belum memanfaatkan leaflet yang ada di tempat tersebut. Smart box juga dapat membantu perawat dalam memberikan penyuluhan kesehatan dengan cukup mudah.

Peran perawat disini sangat penting dan dibutuhkan untuk memberikan penyuluhan berupa informasi kesehatan tentang penyakit yang ada di poli syaraf tersebut diharapakan penyuluhan bisa dilakukan disetiap kesempatan.

Berdasarkan fenomena di atas maka peneliti ingin mengidentifikasi efektifitas penggunaan smart box education dalam pemberian penyuluhan kesehatan pada pasien gangguan persyarafan di poli syaraf RSUD Ngudi Waluyo Wlingi

\section{Metode}

Desain dan metode penelitian.

Penelitian ini menggunakan quasy experimental (pretest posttest design). Ciri penelitian ini mengungkapkan hubungan sebab akibat dengan eksperimen yaitu 
peneliti memberikan perlakuan, dimana observasi dilakukan sebanyak dua kali sebelum dan sesudah eksperimen. Selain itu juga menggunakan 2 kelompok yaitu kelompok perlakuan dan kelompok kontrol.

Populasi dan sampel penelitian

Populasi adalah keluarga pasien gangguan persyarafan di poli syaraf RSUD Ngudi Waluyo Wlingi sejumlah 25 responden yang diambil dengan teknik simple random sampling .

Variabel penelitian

Variabel bebas penelitian ini adalah penyuluhan kesehatan dengan smart box education dan variabel terikat penelitian ini adalah pelaksanaan penyuluhan kesehatan di Poli Syaraf RSUD Ngudi Waluyo Wlingi.

Teknik pengumpulan data.

Setelah penyelesaian ijin penelitian selanjutnya melakukan identifikasi pelaksanaan penyuluhan kesehatan kelompok kontrol di poli syaraf RSUD Ngudi Waluyo Wlingi sebelum penggunaan smart box education dengan menggunakan leaflet penyuluhan saja. Selanjutnya responden (kelompok perlakuan) diberikan penyuluhan dengan menggunakan media smart box education.
Teknik Pengolahan dan Analisa Data. Untuk mengetahui perbedaan efektifitas penyuluhan kesehatan dengan smart box education dilakukan uji t tidak berpasangan dengan menggunakan program SPSS 17 for Window dengan tingkat kemaknaan $(\mathrm{p} \leq 0,05)$.

\section{Hasil}

Karakteristik responden berdasarkan usia

Dari total 25 responden, yang berusia lebih dari 45 tahun adalah 16 responden, usia 31-45 tahun adalah 5 responden dan usia 2030 tahun adalah 4 responden (gambar 1)

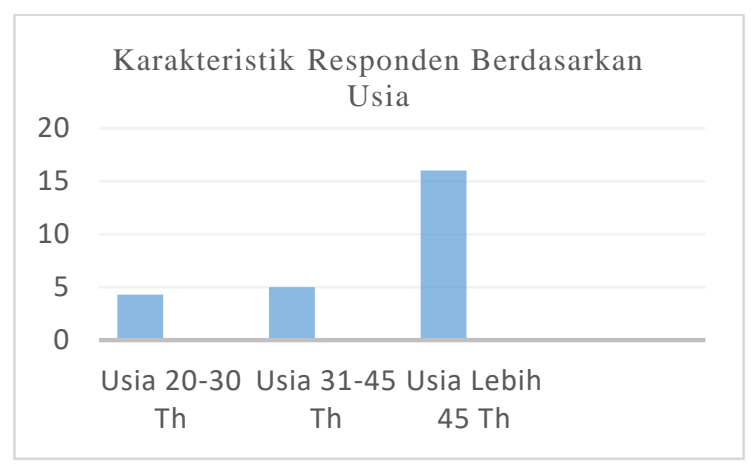

Gambar 1.Karakteristik responden berdasarkan usia di Poli Syaraf RSU Ngudi Waluyo Wlingi

Karakteristik responden berdasarkan jenis kelamin. Dari total 25 responden, 12 berjenis kelamin laki-laki dan 13 orang (52\%) berjenis kelamin perempuan 


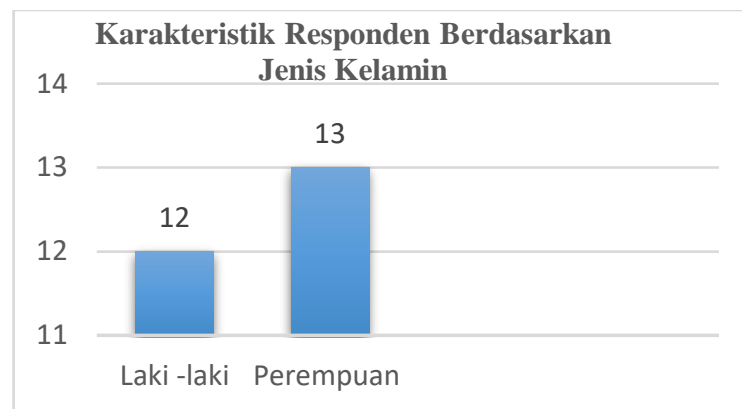

Gambar 2. Karakteristik responden berdasarkan jenis kelamin di Poli Syaraf RSU Ngudi Waluyo Wlingi

Karakteristik responden berdasarkan pendidikan. Dari total 25 responden, paling banyak yaitu 7 orang $(25 \%)$ berpendidikan SMA, 6 orang berpendidikan SMP dan paling sedikit yaitu 1 orang berpendidikan D1

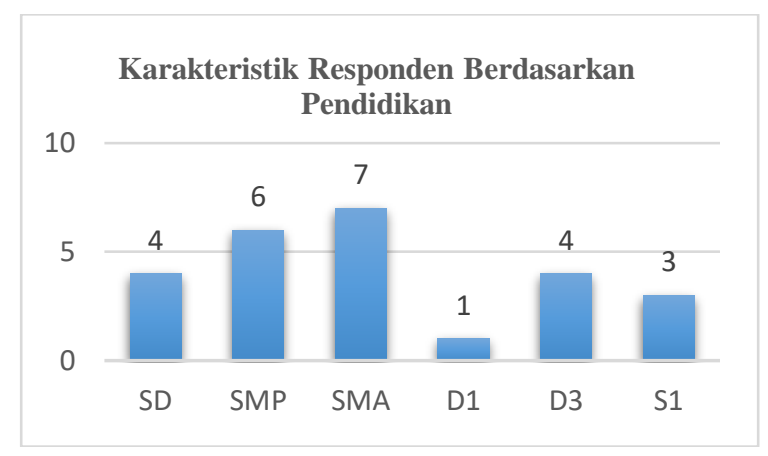

Gambar 3. Karakteristik responden berdasarkan pendidikan di Poli Syaraf RSU Ngudi Waluyo Wlingi

Karakteristik responden berdasarkan jenis penyakit. Semua responden dalam penelitian ini adalah penderita stroke

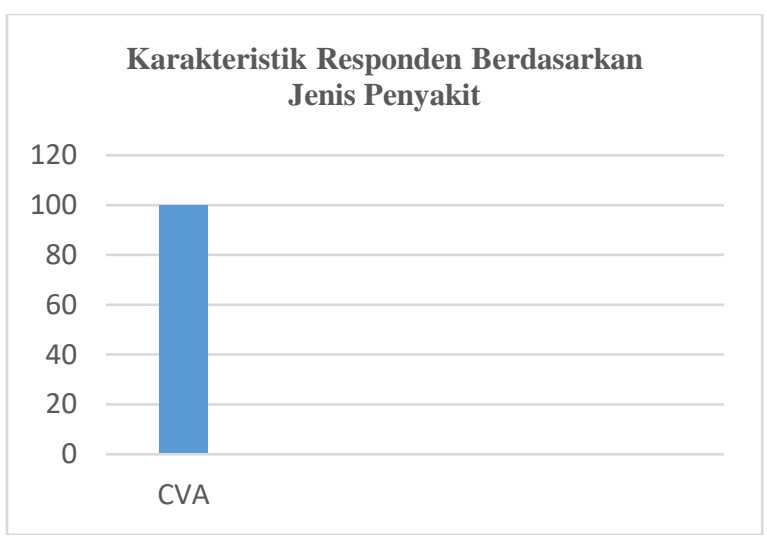

Gambar 4. Karakteristik Responden berdasarkan Jenis Penyakit

Pelaksananaan penyuluhan kesehatan di Poliklinik dan faktor yang mempengaruhi pelaksanaan penyuluhan kesehatan di poli Syaraf RSUD Ngudi Waluyo Wlingi.

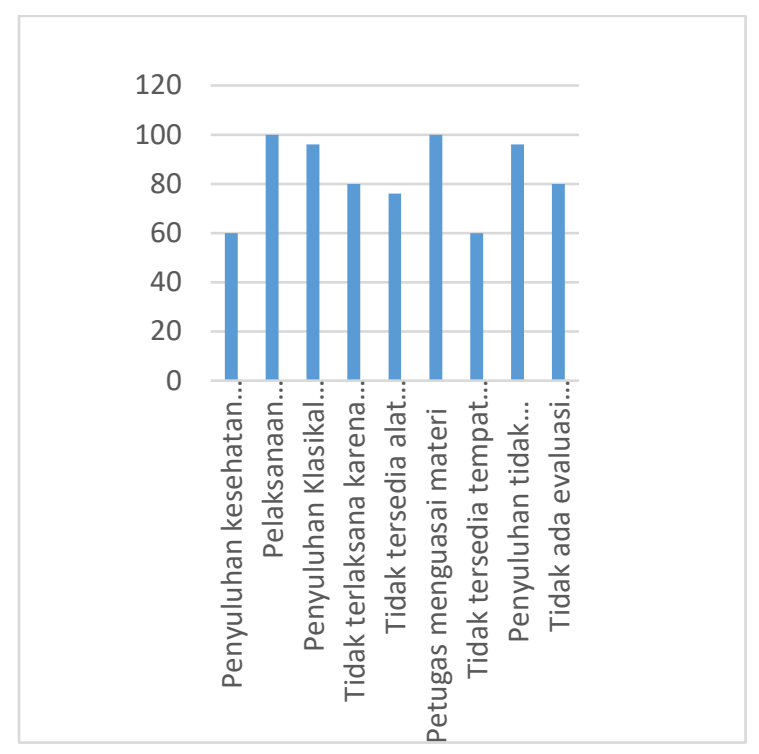

Gambar 5. Pelaksananaan penyuluhan kesehatan di Poliklinik dan faktor yang mempengaruhi pelaksanaan penyuluhan kesehatan di poli Syaraf RSUD Ngudi Waluyo Wlingi. 
Berdasarkan gambar 5 dapat diinterpretasikan bahwa Pelaksanaan Penyuluhan Kesehatan di poliklinik hanya 40 $\%$ menyatakan baik dan sisanya $60 \%$ menyatakan penyuluhan kesehatan tidak berjalan dengan baik. Hampir semua responden menyatakan pelaksanaan penyuluhan setiap kali pasien akan pulang. Sehingga pelaksanaan penyuluhan klasikal tidak pernah dilaksanakan, sebagian besar menyatakan tidak pernah penyuluhan klasikal ( $96 \%$ ).

Dari faktor sarana dapat diketahui bahwa $64 \%$ menyatakan tidak tersedia leaflet yang lengkap untuk dipelajari oleh pasien dan keluarga. Sarana prasarana penyuluhan seperti alat penyuluhan (media), sound sistem,alat tulis sebagian besar tidak tersedia yang dinyatakan oleh $76 \%$ responden. Tempat penyuluhan di poliklinik belum tersedia sebanyak $60 \%$ responden.

Faktor SDM dapat diinterpretasikan bahwa $100 \%$ perawat sebenarnya menguasai materi penyuluhan dan kekurangan SDM menyebabkan penyuluhan tidak berjalan dengan baik.

Faktor manajerial RS menyatakan bahwa $80 \%$ manajemen belum melakukan evaluasi terhadap pelaksanaan penyuluhan di poliklinik .
Pelaksanaan penyuluhan kesehatan sebelum penggunaan Smart Box Education dengan media leaflet.

Tabel 1. Pelaksanaan penyuluhan kesehatan pada pasien gangguan persyarafan di poli syaraf RSUD Ngudi Waluyo Wlingi sebelum penggunaan Smart Box Education dengan media leaflet.

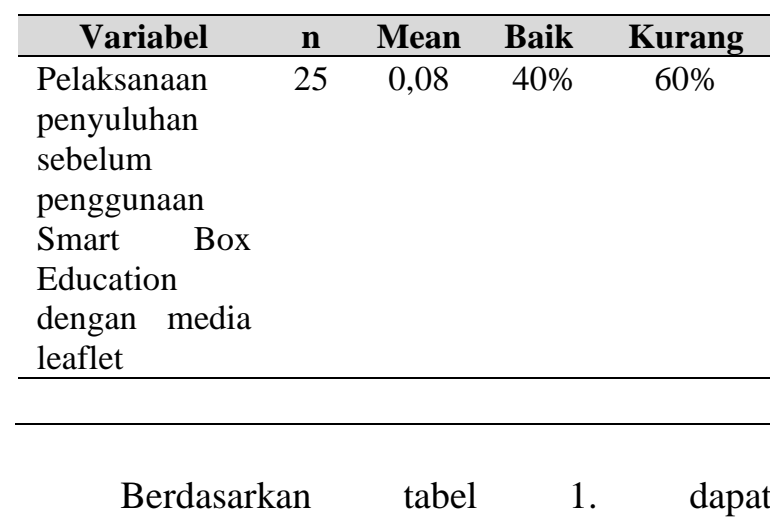
diinterpretasikan bahwa dari 25 responden di Poli Syaraf semuanya ( $60 \%)$ menyatakan pelaksanaan penyuluhan kurang maksimal.

Pelaksanaan penyuluhan kesehatan setelah penggunaan Smart Box Education dengan media leaflet.

Tabel 2. Pelaksanaan penyuluhan kesehatan pada pasien gangguan persyarafan di poli syaraf RSUD Ngudi Waluyo Wlingi setelah penggunaan Smart Box Education dengan media leaflet.

\begin{tabular}{lllll}
\hline \multicolumn{1}{c}{ Variabel } & n & Mean & Baik & Kurang \\
\hline $\begin{array}{l}\text { Pelaksanaan } \\
\text { penyuluhan }\end{array}$ & 25 & 0,96 & $72 \%$ & $28 \%$ \\
sebelum & & & & \\
penggunaan & & & & \\
Smart Box & & & \\
Education \\
dengan media \\
leaflet
\end{tabular}


Berdasarkan tabel 2 dapat kontrol ulang dan perawatan di rumah, diinterpretasikan bahwa dari 25 responden di Poli Syaraf semuanya ( $72 \%$ ) menyatakan pelaksanaan penyuluhan baik.

Hasil interview dengan petugas perawat di poli syaraf.

Keterbatasan petugas kesehatan dalam penyuluhan perawat hanya 1 dan harus berbagi sebagai operator EEG. Keterbatasan waktu dalam pelaksanaan penyuluhan disebabkan jumlah kunjungan pasien mencapai sekitar 800 per bulan dengan rata rata kunjungan per hari 30 pasien dan lama pelayanan per pasien rata rata 20 menit. Pelayanan di mulai dengan pasien datang ke poli syaraf dilakukan anamnesa tentang keluhan dilanjutkan dengan pengukuran tanda vital meliputi Tekanan Darah, Nadi, berat badan. Pemerikasaan tekanan darah elektrik, timbang BB, pemeriksaan neurologi sederhana: kekuatan otot, tonus otot, kemampuan bicara, kemampuan berjalan, reflek menelan. Selanjutnya pemeriksaan kelengkapan administrasi meliputi: kelengkapan persyaratan BPJS, kelengkapan surat elektabilitas pasien dan administrasi pembayaran untuk pasien umum.

Setelah pemeriksaan dokter dan pasien mendapatkan resep selanjutnya perawat memberikan penyuluhan untuk minum obat, jika ada tindak lanjut pemeriksaan foto rontgent, scan dan laboratorium maka perawat akan melakukan koordinasi dengan perawat di unit tersebut untuk penjadwalan kegiatan lanjutan. Jika setelah pemeriksaan pasien di rencanakan opname maka perawat membantu pasien untuk pendaftaran menuju kamar terima dalam pemesanan kamar dan mengantar pasien ke ruangan untuk rawat inap. Pasien yang telah terjadwal pemeriksaan EEG maka perawat melakukan EEG selama kurang lebih 1-2 jam.

Pemeriksaan EEG membutuhkan waktu yang lama karena melakukan beberpa prosedur ini meliputi informed consent di dahului penjelasan prosedur EEG, menenangkan pasien jika pasien tampak tidak nyaman, melakukan pengukuran lokasi utuk menentukan titik titik sadapan gelombang otak (jika pasien wanita harus membuat ikatan untuk membebaskan kulit kepala dari rambut pasien selanjutnya melakukan pemasangan titik titik sadapan dan melakukan perekaman. Selama melakukan perekaman apabila posisi tidak tepat maka perawat melakukan pembetulan posisi sedemikian rupa sehingga perekaman membutuhkan waktu yang lama. 
Pengaruh penggunaan smart box education dalam pemberian penyuluhan kesehatan pada pasien gangguan persyarafan di poli syaraf RSUD Ngudi Waluyo Wlingi.

Tabel 3. Perbedaan pelaksanaan penyuluhan kesehatan pada pasien gangguan persyarafan di poli syaraf RSUD Ngudi Waluyo Wlingi sebelum dan setelah penggunaan Smart Box Education dengan media leaflet.

\begin{tabular}{llllll}
\hline & $\mathrm{n}$ & Median & $p$ \\
\hline Pelaksanaan penyuluhan sebelum penggunaan Smart Box & 25 & $0(0-40)$ & 0,002 \\
Education dengan media leaflet. & & & &
\end{tabular}

Pelaksanaan penyuluhan setelah penggunaan Smart Box 25 100(60-100)

Education dengan media leaflet

Berdasarkan tabel 3 dapat diinterpretasikan bahwa hasil uji Wilcoxon menunjukkan nilai signifikansi sebesar 0.002, oleh karena signifikansi lebih kecil dari $0,05(0,000<0,05)$, yang berarti ada perbedaan yang signifikan pelaksanaan penyuluhan kesehatan pada pasien gangguan persyarafan di poli syaraf RSUD Ngudi Waluyo Wlingi sebelum dan setelah penggunaan Smart Box Education dengan media leaflet.

Hal ini mengindikasikan bahwa dengan penggunaan Smart Box Education dengan media leaflet

dapat berpengaruh positif terhadap peningkatan pelaksanaan penyuluhan kesehatan pada pasien gangguan persyarafan di poli syaraf RSUD Ngudi Waluyo Wlingi.

\section{Pembahasan}

Pelaksananaan penyuluhan kesehatan di Poliklinik dan faktor yang mempengaruhi pelaksanaan penyuluhan kesehatan di poli RSUD Ngudi Waluyo Wlingi.

Menurut Haryani dkk (2016) penyuluhan kesehatan merupakan cara yang digunakan untuk menyampaikan informasi kesehatan. Penyuluhan dapat dilakukan langsung melalui metode tatap muka atau dengan menggunakan media massa sebagai sarana dalam penyampaian informasi. Pelaksanaan penyuluhan di poliklinik rata rata dilaksanakan pada saat penyampaian informasi pasien yang akan pulang bersamaan dengan penjelasan perawatan di rumah, kepatuhan minum obat, mobilisasi 
dll. Penyuluhan bersifat individu dan tidak dilakukan pada waktu tersendiri sehingga menimbulkan beberapa kekurangan diantaranya pasien dan keluarga tidak merasakan penjelasan secara menyeluruh karena keterbatasan waktu. Semua poliklinik (100\%) tidak melaksanakan penyuluhan klasikal karena selain keterbatasan juga kurangnya waktu, tempat dan tenaga penyuluh. Hal ini sesuai dengan Susanti (2011) menyatakan bahwa ada peningkatan pengetahuan yang signifikan setelah diberikan intervensi pendidikan kesehatan, sehingga pendidikan kesehatan melalui penyuluhan sangat dibutuhkan oleh pasien dan keluarganya.

Menurut responden hal ini disebabkan oleh karena kurang terjalinnya koordinasi antara Humas Rumah Sakit dengan Poliklinik. Kurangnya sarana dan prasarana penyuluhan yaitu belum adanya ruang khusus PKMRS, Tenaga Penyuluh ( Promosi Kesehatan), tidak ada jadwal khusus PKMRS dari Humas, kurangnya evaluasi program PKMRS oleh seluruh staff poliklinik dan Humas RS. Pelaksanaan pemberian informasi yang terlaksana yaitu penyediaan leaflet -leaflet tentang penanganan penyakit yang diletakkan di meja perawat tetapi menurut keluarga kadang tidak tersampaikan kepada keluarga dan pasien. Belum ada tempat tersendiri untuk tempat leaflet.

Minat baca keluarga dan pasien sangat kurang, terbukti ketika leaflet diberikan dan di tanyakan ulang tentang isinya, hampir semua keluarga dan pasien belum membaca leaflet. Meskipun membaca kadang ada beberapa ungkapan yang tidak jelas dan bisa dipahami oleh pasien. Kebijakan Nasional Promosi Kesehatan dan Keputusan Menteri Kesehatan Nomor 1114/Menkes/SK/VIII/2005 2005 tentang Pedoman Pelaksanaan Promosi Kesehatan di Daerah menyebutkan strategi dasar utama Promosi Kesehatan adalah pemberdayaan,yang didukung oleh bina suasana, advokasi dan kemitraan. Sehingga RS sangat berkepentingan dalam menyediakan sarana prasarana dan SDM yang dibutuhkan dalam penyuluhan kesehatan.

Pelaksanaan penyuluhan kesehatan pada pasien gangguan persyarafan di poli syaraf RSUD Ngudi Waluyo Wlingi sebelum penggunaan smart box education dengan media leaflet.

Berdasarkan gambar 5.6 dapat diinterpretasikan bahwa dari 25 responden di Poli Syaraf semuanya ( $60 \%$ ) menyatakan pelaksanaan penyuluhan kurang. Seperti di 
poliklinik lain, di poli syaraf penyuluhan secara klasikal tidak pernah dilakukan. Hal ini juga ditunjang dengan belum ada media yang memudahkan perawat memberikan penyuluhan di Poli Syaraf. Selama ini penyuluhan hanya bersifat informasi per individu yang kadang mengakibatkan kurang dipahaminya materi penyuluhan baik oleh keluarga maupun pasien. Materi kurang bervariasi dan hanya mengandalkan leaflet yang ada.Sehingga perlu adanya media yang dapat membantu perawat dalam penyuluhan dan bisa dimanfaatkan keluarga/pasien saat menunggu pemeriksaan di poli Syaraf. Keadaan ini sesuai dengan Keputusan Menteri Kesehatan Nomor 1193/Menkes/SK/X/2004 tentang Kebijakan Nasional Promosi Kesehatan dan Keputusan Menteri Kesehatan Nomor 1114/Menkes/SK/VIII/2005 tentang Pedoman Pelaksanaan Promosi Kesehatan di Daerah menyebutkan strategi dasar utama Promosi Kesehatan adalah pemberdayaan,yang didukung oleh bina suasana, advokasi dan kemitraan. Pemberdayaan adalah ujung tombak dari upaya PKRS. Pada hakikatnya pemberdayaan adalah upaya membantu atau memfasilitasi pasien/klien, sehingga memiliki pengetahuan, kemauan, dan kemampuan untuk mencegah dan atau mengatasi masalah kesehatan yang dihadapinya, oleh karena itu pemberdayaan hanya dapat dilakukan terhadap pasien/klien. Pemberdayaan ini selain melibatkan pasien juga melibatkan manajemen serta humas rumah sakit dalam meningkatkan layanan penyuluhan kesehatan.

\section{Pelaksanaan penyuluhan kesehatan pada pasien gangguan persyarafan di poli syaraf RSUD Ngudi Waluyo Wlingi setelah penggunaan smart box education.}

Berdasarkan gambar 5.7 dapat diinterpretasikan bahwa dari 25 responden di Poli Syaraf semuanya ( $72 \%$ ) menyatakan pelaksanaan penyuluhan baik. Smart box Education adalah perangkat alat modern yang bersifat elektronik karya peneliti yang dipergunakan untuk mempermudahkan seseorang dalam mendapatkan penyuluhan kesehatan, di mana dasarnya banyak pengunjung yang belum memanfaatkan leaflet yang ada di tempat tersebut. Smart box education juga dapat membantu perawat dalam memberikan penyuluhan kesehatan dengan cukup mudah.

Cara menggunakan smart box education sangat mudah yaitu hanya dengan mengambil dan memasang head set tekan tombol on off kemudian duduk sambil mendengarkan penjelasan yang ada, 
pengunjung akan mendapatkan penjelasan tentang penyakit yang banyak di derita di ruangan tersebut mulai dari pengertian, tanda gejala, komplikasi, pencegahan dan pengobatannya.

Perangkat yang pintar tentunya banyak sekali kegunaannya tidak terkecuali smart box yang berbasis elektronik. Agar penggunakan maksimal maka diperlukan perawatan yang baik dan benar seperti perangkat pintar lainnya. Susanti (2011) menyatakan bahwa ada peningkatan pengetahuan yang signifikan setelah diberikan intervensi pendidikan kesehatan dengan menggunakan media $81,46 \%$. Hal ini karena media dapat menampilkan gambar dan bahasa yang mudah dimengerti oleh sasaran. Menurut Notoatmodjo (2003), bahwa seseorang dapat belajar melalui panca inderanya. Seseorang yang dapat mengingat hasil belajar dengan baik dan dapat menggunakan pancaindera lebih dari satu pancaindera melalui apa yang dilihat dan didengarnya sebesar 50\%. Rahmah (2011) menyatakan bahwa adanya peningkatan kognitif, afektif dan psikomotor setelah diberikan penyuluhan kesehatan dengan menggunakan media. Menurut Gupta dan Guptha (2010), media yang informatif dan menarik akan efektif digunakan dalam promosi kesehatan seperti promosi tentang nutrisi, gaya hidup, dan mempromosikan hasil penelitian yang lainnya.

Pengaruh penggunaan smart box education dalam pemberian penyuluhan kesehatan pada pasien gangguan persyarafan di poli syaraf RSUD Ngudi Waluyo Wlingi.

Berdasarkan tabel 5 dapat diinterpretasikan bahwa hasil uji Wilcoxon menunjukkan nilai signifikansi sebesar 0.002, oleh karena signifikansi lebih kecil dari $0,05(0,000<0,05)$, yang berarti ada perbedaan yang signifikan pelaksanaan penyuluhan kesehatan pada pasien gangguan persyarafan di poli syaraf RSUD Ngudi Waluyo Wlingi sebelum dan setelah penggunaan Smart Box Education dengan media leaflet. Hal ini mengindikasikan bahwa dengan penggunaan Smart Box Education dengan media leaflet dapat berpengaruh positif terhadap peningkatan pelaksanaan penyuluhan kesehatan pada pasien gangguan persyarafan di poli syaraf RSUD Ngudi Waluyo Wlingi. Kelebihan media ini adalah:

1. Pengunjung lebih mudah mendapatkan penyuluhan kesehatan

2. Memudahkan perawat dalam memberikan penyuluhan 
3. Terlaksananya penyuluhan kesehatan tentang penyakit gangguan persyarafan.

4. Penyuluhan dapat berjalan tanpa tergantung perawat

5. Media rekaman yang ekonomis

6. Interaktif dan menarik

7. Keluarga/penderita bisa memaanfaatkan waktu menunggu dengan mendapatkan pengetahuan kesehatan.

8. Keluarga/penderita dapat lebih memahami pengertian, tanda gejala, komplikasi, pencegahan dan pengobatannya.

Menurut Gupta dan Guptha (2010), media yang informatif dan menarik akan efektif digunakan dalam promosi kesehatan seperti promosi tentang nutrisi, gaya hidup, dan mempromosikan hasil penelitian yang lainnya.

Media memiliki multi makna, baik dilihat secara terbatas maupun secara luas. Harsoyo (2002) memaknai media sebagai segala bentuk yang dimanfaatkan dalam proses penyaluran informasi. Media secara luas/makro dalam sistem pendidikan sehingga mendefinisikan media adalah segala sesuatu yang dapat merangsang terjadinya proses belajar pada diri peserta didik.
Smart

box

Education

mempermudahkan seseorang dalam mendapatkan penyuluhan kesehatan, di mana dasarnya banyak pengunjung yang belum memanfaatkan leaflet yang ada di tempat tersebut. Smart box education juga dapat membantu perawat dalam memberikan penyuluhan kesehatan dengan cukup mudah.

\section{Kesimpulan dan Saran}

\section{Kesimpulan}

Berdasarkan hasil penelitian yang telah dilaksanakan dapat dirumuskan kesimpulan sebagai berikut:

1. Pelaksanaan Penyuluhan Kesehatan di poliklinik hanya $40 \%$ menyatakan baik dan sisanya $60 \%$ menyatakan penyuluhan kesehatan tidak berjalan dengan baik. Hampir semua responden menyatakan pelaksanaan penyuluhan setiap kali pasien akan pulang. Sehingga pelaksanaan penyuluhan klasikal tidak pernah dilaksanakan, sebagian besar menyatakan tidak pernah penyuluhan klasikal ( $96 \%$ ).Dari faktor sarana dapat diketahui bahwa $64 \%$ menyatakan tidak tersedia leaflet yang lengkap untuk dipelajari oleh pasien dan keluarga. Sarana prasarana penyuluhan seperti alat penyuluhan ( media ), sound system,alat 
tulis sebagian besar tidak tersedia yang dinyatakan oleh $76 \%$ responden. Tempat penyuluhan di poliklinik belum tersedia sebanyak $60 \%$ responden. perawat sebenarnya menguasai materi penyuluhan dan kekurangan SDM menyebabkan penyuluhan tidak berjalan dengan baik. Faktor manajerial RS menyatakan bahwa $80 \%$ manajemen belum melakukan evaluasi terhadap pelaksanaan penyuluhan di poliklinik .

2. Pelaksanaan penyuluhan kesehatan pada pasien gangguan persyarafan di poli syaraf RSUD Ngudi Waluyo Wlingi sebelum penggunaan Smart Box Education dengan media leaflet dari 25 responden di Poli Syaraf semuanya ( 60 $\%)$ menyatakan pelaksanaan penyuluhan kurang.

3. Pelaksanaan penyuluhan kesehatan pada pasien gangguan persyarafan di poli syaraf RSUD Ngudi Waluyo Wlingi setelah penggunaan Smart Box Education dengan media leaflet diinterpretasikan bahwa dari 25 responden di Poli Syaraf semuanya (72\%) menyatakan pelaksanaan penyuluhan baik.

4. Berdasarkan hasil uji Wilcoxon menunjukkan nilai signifikansi sebesar 0.002, oleh karena signifikansi lebih kecil dari $0,05(0,000<0,05)$, yang berarti ada perbedaan yang signifikan pelaksanaan penyuluhan kesehatan pada pasien gangguan persyarafan di poli syaraf RSUD Ngudi Waluyo Wlingi sebelum dan setelah penggunaan Smart Box Education dengan media leaflet.Hal ini mengindikasikan bahwa dengan penggunaan Smart Box Education dengan media leaflet dapat berpengaruh positif terhadap peningkatan pelaksanaan penyuluhan kesehatan pada pasien gangguan persyarafan di poli syaraf RSUD Ngudi Waluyo Wlingi.

\section{Saran}

\section{Bagi Rumah Sakit.}

Perlu menyediakan leaflet yang lengkap untuk dipelajari oleh pasien dan keluarga. Penambahan Sarana prasarana penyuluhan seperti alat penyuluhan ( media), sound system,alat tulis serta tempat penyuluhan di poliklinik . Penambahan SDM untuk memberikan pemecahan kekurangan SDM yang menyebabkan penyuluhan tidak berjalan dengan baik. Pihak manajemen khususnya Humas RS secara rutin melakukan evaluasi terhadap pelaksanaan penyuluhan di poliklinik.

\section{Bagi Poliklinik Syaraf.}

Pelaksanaan Penyuluhan Kesehatan di poliklinik syaraf sebaiknya dilakukan secara 
klasikal sehingga pasien dan keluarga paham tentang materi penyuluhan. Pemanfaatan media Smart Box Education di rekomendasikan untuk poli Syaraf guna mengatasi keterbatsaan tenaga dalam penyuluhan.

\section{Bagi peneliti lain.}

Peneliti selanjutnya direkomendasikan untuk melakukan penelitian tentang media innovative yang dapat meningkatkan pelaksanaan penyuluhan khususnya di poliklinik. Media sedapat mungkin lebih interaktif dan bisa bersifat audi visual sehingga lebih mudah meningkatkan pemahaman isi materi penyuluhan.

\section{Referensi}

Alimul A. (2007) Metode Penelitian Keperawatan dan Analisa Data. Jakarta: Salemba Medika;

Allender J, Spradley B. (2010) Community health nursing: Promoting and protecting the public's health 6, editor. Philadelphia: Lippincott Williams \& Wilkins.

Arikunto S. (2006). Prosedur Penelitian. Jakarta: Rineka Cipta;

Azwar S. (2002.) Sikap Manusia. Yogyakarta: Pustaka Pelajar.
Bensley R, Fisher J. (2003). Metode Pendidikan Kesehatan Masyarakat 2, editor. Jakarta: EGC

Carretero O, Oparil S. (2000) Clinical cardiology: New frontiers. Circulation. 101:329-35.

Effendy. (1998). Dasar-dasar Keperawatan Kesehatan Masyarakat. Jakarta EGC.

Gupta R, Guptha S. (2010) Strategies for initial management of hypertension. Indian J Med Res. 132(5):531-42.

Handayani. (2016). Penyuluhan Kesehatan Melalui Media Cetak Berpengaruh Terhadap Perawatan Hipertensi Pada Usia Dewasa Di Kota Depok Jurnal Keperawatan Indonesia 2016;19(3):161-8.

Promosi Kesehatan . (2004.) Pengembangan Media Promosi Kesehatan. Jakarta: Departemen Kesehatan $\mathrm{RI}$;

Promosi Kesehatan. (2008). Pedoman Pengelolaan Promosi Kesehatan, Dalam Pencapaian PHBS. Jakarta Departemen Kesehatan RI.

Notoatmodjo. (2003). Pendidikan Dan Perilaku Kesehatan. Jakarta: Rineka Cipta; 
Notoatmodjo. (2005). Metodologi Penelitian

Kesehatan. Jakarta: Rineka Cipta.

Notoatmodjo. (2007) Kesehatan Masyarakat

Ilmu dan Seni. Jakarta: Rineka

Cipta.

Setiawan H, Suhanda, Roslianti E,

Firmansyah A, Fitriani A. (2003.)

Promosi Kesehatan Pencegahan

Hipertensi Sejak Dini. JURNAL

ABDIMAS UMTAS. 1(2). 